\title{
Do fruit bats deserve to be listed as vermin in the Indian Wildlife (Protection) \& Amended Acts? A critical review
}

\author{
Natarajan Singaravelan, Ganapathy Marimuthu and Paul A. Racey
}

\begin{abstract}
Of the 13 species of fruit bats occurring in India, the Indian flying fox Pteropus giganteus, the dog-faced fruit bat Rousettus leschenaultii and the greater short-nosed fruit bat Cynopterus sphinx are distributed throughout the country. They usually live in trees $(P$. giganteus $)$, temples and caves ( $R$. leschenaultii) and foliage (C. sphinx) and feed on fruits such as fig Ficus spp., Singapore cherry Muntingia calabura, Indian almond Terminalia catappa, mango Mangifera indica, guava Psidium guajava as well as leaves, nectar and pollen. The other 10 species live at sea level and at altitudes of $>2,000 \mathrm{~m}$ and their distribution and foraging activities may be restricted mainly to forests. Two of them, the Nicobar flying fox Pteropus faunulus and Salim Ali's fruit bat Latidens salimalii are endemic. Although details of their foraging activity are poorly known, there is no evidence that they visit commercial fruit orchards. They feed on wild fruits and disperse seeds widely, contributing to forest regeneration. Although P. giganteus, R. leschenaultii and C. sphinx feed on commercial fruits, their role in pollination and seed dispersal of economically important plants such as kapok Ceiba pentandra, mahua Bassia latifolia and petai Parkia spp. is important. Sacrificial crops such as $M$. calabura can be used at orchards to reduce the damage bats cause to commercial fruit. Because the ecological services provided by bats are not appreciated by the public and conservation planners, all fruit bat species with one exception are still categorized as vermin and included as such in Schedule V of the Indian Wildlife (Protection) Act, 1972 and amended Acts. It is now appropriate for the Government of India to revisit this issue and consider removing these pollinators and seed dispersers from the list of vermin in the Wildlife (Protection) Act.
\end{abstract}

Keywords Conservation policy, fruit bats, India, pollination, seed dispersal, vermin, Wildlife Amended Acts

\footnotetext{
Natarajan Singaravelan* and Ganapathy Marimuthu Department of Animal Behaviour \& Physiology, Madurai Kamaraj University, Madurai, India.

PAul A. RACEY (Corresponding author) School of Biological Sciences, University of Aberdeen, Tillydrone Avenue, Aberdeen, AB24 2TZ, UK. E-mail p.racey@abdn.ac.uk

${ }^{*}$ Current address: Institute of Evolution, University of Haifa, Mount Carmel, Israel.

Received 26 February 2008. Revision requested 16 May 2008. Accepted 4 July 2008.
}

\section{Introduction}

$\mathrm{B}$ ats (Chiroptera) are the second largest order of mamBals, with $>1,116$ species (Simmons, 2005). Among them c. 183 belong to the family Pteropodidae and are essentially vegetarian, eating fruit, pollen, nectar and leaves, and the remainder have more varied diets that include frugivory, although most are insectivores. But within the Old World, including India, only pteropodids eat fruit, consuming a wide variety of commercial and non-commercial species (Marshall, 1985). They play a pivotal role as pollinators and seed dispersers of many plants and in tropical forest succession (Start \& Marshall, 1976; Fleming \& Estrada, 1993; Fleming \& Sosa, 1994; Banack, 1998; Muscarella \& Fleming, 2007). At least 300 plant species of nearly 200 genera rely mainly on Old World fruit bats for their propagation (Marshall, 1983, 1985; Fujita \& Tuttle, 1991). Furthermore, these plants produce $\mathrm{c}$. 500 economically valuable products including fruits, dyes, tannins, timber, medicines, fibres and fuelwood (Fujita \& Tuttle, 1991). The importance of bats for the future availability of these products is substantial and has been seriously underestimated.

\section{Bats as pollinators and seed-dispersers}

Fruit bats are mobile foragers (Fleming \& Sosa, 1994), moving genetic material in the form of pollen between isolated fragments of vegetation and depositing seeds over large areas (Young et al., 1996; Law \& Lean, 1999). They are the sole or prime pollinators of several nectariferous plants that flower only at night (e.g. kapok Ceiba, petai Parkia, durian Durio, Oroxylum, stinking passion Passiflora and banana Musa), many of which are economically important. For example, Ceiba pentandra yields a commercially valuable fibre, which is used for stuffing cushions and mattresses (Fujita \& Tuttle, 1991). Durio and Parkia fruits are commercially important foods in some parts of South-East Asia (Fujita, 1988).

Zoochory (seed dispersal by animals) is particularly widespread among pioneer plants and nearly half of the most abundant species are bat-dispersed (Charles-Dominique, 1986). Fruit bats disperse seeds in two ways. Fruits may be carried away from the parent tree and the seeds subsequently dropped under a feeding roost. Alternatively, smaller seeds are ingested along with the fruit pulp and pass through the gut to be voided in the faeces, often away from parent trees. The success of self-regeneration 
for many tropical trees improves if their propagules are moved away from the parents (Janzen, 1983). Smaller pteropodid bats can fly up to $35 \mathrm{~km}$ nightly in search of food, and the larger ones (Pteropus spp.) can fly for longer distances (Nelson, 1965). Because they defecate or drop large numbers of seeds in flight, these bats are able to move seeds over longer distances and wider areas than any other rainforest animals. In addition, it has been suggested that passage through the bat gut improves the levels of seed germination (Izhaki et al., 1995).

Plants that have relatively large-seeded fruits are consumed by fewer dispersers, and depend on fewer species of mammals (Corlett, 1998). The carriage of such fruits is considered to be the primary dispersal role of Pteropus (Richards, 1995). These pteropodid bats are thus important vehicles of plant dispersal and are able to bridge the gaps between widely separated forest fragments (Corlett, 1998). Several of the world's most important domesticated food staples, including bananas, plantain, breadfruit and mangoes, continue to rely on flying foxes for their propagation in the wild (Fujita \& Tuttle, 1991). However, bananas are spread vegetatively and mangoes are planted by humans in rural villages in India. Wide-ranging seed dispersal encourages genetic exchange between fragments of forests or isolated populations of certain species and decreases the chances of inbreeding (Loveless \& Hamrick, 1984). Through pollination of bat-dependent flowers and dispersal of seeds into forest gaps and clearings, tropical bats play an essential role in forest ecology (Cox et al., 1991; Fujita \& Tuttle, 1991). Thus, they play an important role in secondary succession as well as in maintaining the compositional heterogeneity of tropical forests (Wang \& Smith, 2002).

\section{Fruit bats of India}

Thirteen of the 120 bat species in India are pteropodids (Table 1; Bates \& Harrison, 1997). Pteropus giganteus, Rousettus leschenaultii and Cynopterus sphinx are distributed throughout most of India, generally in lowland areas. The remaining 10 species are restricted mainly to forested and island areas (Bates \& Harrison, 1997). For example, the lesser short-nosed fruit bat Cynopterus brachyotis (Balasingh et al., 1999) and Salim Ali's fruit bat Latidens salimalii (Singaravelan \& Marimuthu, 2003) are confined to the south, especially to the Western Ghats of Tamil Nadu (and possibly also in Kerala). The island flying fox Pteropus hypomelanus lives only on the Andaman islands, the Nicobar flying fox Pteropus faunulus is endemic to the Nicobar islands, and the large or Malayan flying fox Pteropus vampyrus and black-eared flying fox Pteropus melanotus are present on both island archipelagos (Aul, 2006). Similarly Ratanaworabhan's fruit bat Megaerops niphanae and the greater long-tongued fruit bat Macroglossus sobrinus are restricted to north-east India.

Detailed studies on the foraging activity of the three ubiquitous bats $P$. giganteus, $R$. leschenaultii and C. sphinx reveal their role as pollinators of several plant species (Table 2). There is no evidence of individuals of the remaining 10 species, including Pteropus species on the Nicobar and Andaman islands, either being caught in lowland areas or causing damage to commercial fruit orchards. This suggests that these species rely on wild fruits that are available in their forest and island habitats. For example, remnants of wild fruits (the bead tree Eleocarpus oblongus, the Ceylon plum Prunus ceylanicus and the Indian laurel fig Ficus macrocarpa) were collected at the night roosts of

TABLE 1 Name, size and distribution of the 13 species of fruit bats in various states of India (Bates \& Harrison, 1997).

\begin{tabular}{lcl}
\hline Bat species & $\begin{array}{l}\text { Forearm mean } \\
\text { length }(\mathrm{mm})\end{array}$ & Distribution in states \\
\hline $\begin{array}{l}\text { Greater long-tongued fruit bat Macroglossus } \\
\text { sobrinus }\end{array}$ & 47.3 & $\begin{array}{l}\text { Arunachal Pradesh, Megalaya, Mizoram, Tripura, } \\
\text { West Bengal }\end{array}$ \\
$\begin{array}{l}\text { Blanford's fruit bat Sphaerias blanfordi } \\
\text { Ratanaworabhan's fruit bat Megaerops niphanae }\end{array}$ & 54.9 & $\begin{array}{l}\text { Arunachal Pradesh, Uttar Pradesh, West Bengal } \\
\text { Arunachal Pradesh, West Bengal }\end{array}$ \\
Lesser short-nosed fruit bat Cynopterus brachyotis & 58.2 & Kerala, Tamil Nadu \\
Salim Ali's fruit bat Latidens salimalii & 60.3 & Kerala, Tamil Nadu \\
Greater short-nosed fruit bat Cynopterus sphinx & 67.3 & Throughout India (usually in lowlands) \\
Long-tongued dawn fruit bat Eonycteris spelaea & 70.2 & Andaman \& Nicobar Islands, Andhra Pradesh, \\
& 71.2 & Assam, Karnataka, Manipal, Megalaya, Nagaland, \\
& & Uttar Pradesh \\
Dog-faced fruit bat Rousettus leschenaultii & 80.6 & Throughout India (usually in lowlands) \\
Nicobar flying fox Pteropus faunulus & 113 & Nicobar Islands \\
Island flying fox Pteropus hypomelanus & 141 & Andaman Islands \\
Black-eared flying fox Pteropus melanotus & 152.9 & Andaman \& Nicobar Islands \\
Indian flying fox Pteropus giganteus & 168.4 & Throughout India (usually in lowlands) \\
Large or Malayan flying fox Pteropus vampyrus & $\sim 200$ & Andaman \& Nicobar Islands \\
\hline
\end{tabular}


TABLE 2 List of plants that are pollinated by the three ubiquitous fruit bats C. sphinx, R. leschenaultii and P. giganteus, and pollination of these plants by other bat species.

\begin{tabular}{|c|c|c|c|c|c|}
\hline Plant species & $\begin{array}{l}\text { Cynopterus } \\
\text { sphinx }\end{array}$ & $\begin{array}{l}\text { Rousettus } \\
\text { leschenaultii }\end{array}$ & $\begin{array}{l}\text { Pteropus } \\
\text { giganteus }\end{array}$ & $\begin{array}{l}\text { Other } \\
\text { species }\end{array}$ & References \\
\hline Kapok Ceiba pentandra & + & + & + & $\begin{array}{l}\text { Eonycteris } \\
\text { spelaea }\end{array}$ & $\begin{array}{l}\text { Subramanya \& Radhamani, } \\
\text { 1993; Singaravelan \& } \\
\text { Marimuthu, 2004; } \\
\text { Nathan et al., 2005 }\end{array}$ \\
\hline $\begin{array}{l}\text { Silk cotton tree } \\
\text { Bombax ceiba }\end{array}$ & + & + & + & & $\begin{array}{l}\text { Brosset, 1962; Subramanya \& } \\
\text { Radhamani, } 1993\end{array}$ \\
\hline Petai Parkia spp. & + & & + & & $\begin{array}{l}\text { Baker \& Harris, 1957; } \\
\text { Subramanya \& Radhamani, } 1993\end{array}$ \\
\hline Baobab Adansonia digitata & & + & & & Subramanya \& Radhamani, 1993 \\
\hline Sausage tree Kigelia pinnata & + & + & & & $\begin{array}{l}\text { McCann, 1931; Subramanya \& } \\
\text { Radhamani, } 1993\end{array}$ \\
\hline $\begin{array}{l}\text { Indian trumpet flower } \\
\text { Oroxylum indicum }\end{array}$ & + & + & & $\begin{array}{l}\text { Eonycteris } \\
\text { spelaea }\end{array}$ & $\begin{array}{l}\text { Gould, 1978; Subramanya \& } \\
\text { Radhamani, } 1993\end{array}$ \\
\hline Orchid Bauhinia sp. & + & & + & & van der Pijl, 1961; Marshall, 1985 \\
\hline Banana Musa spp. & + & & & & Corlett, 2004 \\
\hline Jamun Eugenia jambolana & & + & & & Brosset, 1962; Marshall, 1985 \\
\hline $\begin{array}{l}\text { Cashew nut Anacardium } \\
\text { occidentale }\end{array}$ & & + & + & & Subramanya \& Radhamani, 1993 \\
\hline Wild guava Careya arborea & & + & & & Corlett, 2004 \\
\hline $\begin{array}{l}\text { Mahua } \\
\quad \text { Madhuca indica }\end{array}$ & + & & + & & Corlett, 2004 \\
\hline $\begin{array}{l}\text { Waras Heterophragma } \\
\quad \text { roxberghii }\end{array}$ & & + & & & Subramanya \& Radhamani, 1993 \\
\hline $\begin{array}{l}\text { Padri tree Radermachera } \\
\quad \text { xylocarpa }\end{array}$ & & + & & & Subramanya \& Radhamani, 1993 \\
\hline Sonneratia spp. & & + & & Macroglossus sp. & Corlett, 2004 \\
\hline $\begin{array}{l}\text { Ceylon wood Mimusops } \\
\text { hexandra }\end{array}$ & & + & & & Subramanya \& Radhamani, 1993 \\
\hline Silky oak Grevillia robusta & & & + & & McCann, 1933 \\
\hline Ganua beccarii & + & & & & Corlett, 2004 \\
\hline Durian Durio zibethinus & + & & & & Gould, 1978 \\
\hline Duabanga Duabanga sp. & + & & & & van der Pijl, 1956 \\
\hline Freycinetia sp. & + & & & & van der Pijl, 1956 \\
\hline Katsagon Haplophragma sp. & + & & & & van der Pijl, 1956 \\
\hline $\begin{array}{l}\text { Sea poison tree } \\
\text { Barringtonia sp. }\end{array}$ & + & & & & Corlett, 2004 \\
\hline Karayani Cullenia exarillata & + & & & & Devy \& Davidar, 2003 \\
\hline
\end{tabular}

L. salimalii (Singaravelan \& Marimuthu, 2003). Eonycteris spelaea feeds mainly on nectar and pollen and pollinates flowers (Bumrungsri et al., 2008) that yield commercial fruits (Bates \& Harrison, 1997).

\section{Fruit bats and the Indian Wildlife (Protection) Act}

Despite their beneficial role, fruit bats have long been hunted as a source of protein and for medicinal use and persecuted as fruit-eating pests. The Indian Wildlife (Protection) Act, 1972, categorizes fruit bats as vermin (which can be captured or killed) under Schedule V. However, killing of bats with such a low reproductive rate (often only 1-2 young per year) results in a reduction in their numbers with consequent effects on pollination and seed dispersal.
A breakdown of plant-pollinator and plant-seed-disperser relationships and subsequent loss of genetic diversity (heterozygosity and allelic diversity) could be one of the most threatening consequences of forest fragmentation (Bawa, 1990; Young et al., 1996). Although categorizing plantvisiting bats as vermin is no longer acceptable, when the Act was formulated (1972) there was a lack of adequate scientific evidence about the ecological roles of fruit bats, with ecological research, particularly on plant-visiting bats, in its infancy. However, three amendments have been made to the Act. Although the efforts of bat conservationists, particularly the Chiroptera Conservation and Information Network of South Asia (CCINSA), to shift India's fruit bats to Schedule I (i.e. to be protected) met with little early success, the Wildlife (Protection) Amended Act, 2002 
placed the endemic fruit bat $L$. salimalii as well as Wroughton's free-tailed bat Otomops wroughtoni in Schedule I. This fell short of removing all fruit bat species from the list of vermin, which is the aim of CCINSA (Molur et al., 2002) and other organizations, including Bat Conservation International (Mistry, 2003) and IUCN's Species Survival Commission (Mickleburgh et al., 1992, 2002).

\section{Mitigating bat damage to commercial fruits}

Bat researchers have documented the incidence of bats visiting orchards. Large-scale commercial growing of fruits has led to conflicts between fruit growers and bats in Australia (Loebel \& Sanewski, 1987; Tidemann et al., 1997), Israel (Moran \& Keidar, 1993), South Africa (Jacobsen \& DuPlessis, 1976), Malaysia and Indonesia (Fujita, 1988) and India (Vergheese, 1998; Srinivasulu \& Srinivasulu, 2001). The most serious conflicts may occur where the supply of native fruits has been reduced through habitat loss (Tidemann \& Nelson, 1987).

Although fruit bats are considered to be pests in commercial orchards, a recent study (Singaravelan, 2002) argues that the menace of bats is mainly restricted to those guava and mango orchards where harvesting is delayed and that c. $60 \%$ of fruits that were damaged by bats were ripe or overripe. The latter are not marketable even if the bats did not damage them. Fruit growers usually sell the ripe fruits to local markets where they often fetch half the price of less ripe fruit, which is sold further afield.

Recently C. sphinx has been blamed for damage to grapes (Vergheese, 1998; Srinivasulu \& Srinivasulu, 2001, 2002). However, the bats inflicted only $4 \%$ of the observed damage and birds (purple sunbird Nectaria asiatica, redvented bulbul Pycnonotus cafer, white-eye or spectacle bird Zosterops palpebrosa) ate or damaged c. $30 \%$ of the grape crops (Singaravelan, 2002).

To reduce the damage caused by fruit bats in orchards, several non-destructive control measures have been suggested (Hall \& Richards, 1987; Vergheese, 1998). There are two feasible and effective measures that yield considerable success: crop protection at the orchard and farm management. The former includes the use of scare guns, light grids over orchards, chemical repellents and netting. The latter involves removal of early ripening fruits and the establishment of suitable sacrificial crops. However, crop protection at orchards is suggested for large-scale commercial fruit growers where Pteropus damage is substantial, as in Australia. Bat attacks on those orchards that incorporate harvesting were minimal (Singaravelan, 2002). Thus, changes in farm management practice may be the most feasible and successful means of reducing bat damage to commercial fruit.

Although early picking of fruit and early removal of overripe fruit may be effective, planting alternative forage trees with a high sugar content in the proximity of the orchards could alleviate the problem of bat-attacks. The Singapore cherry Muntingia calabura produces a fruit on which several species of bats feed (Bonaccorso \& Gush, 1987). For example, C. sphinx gathers in swarms of 10-30 individuals while feeding on Muntingia fruits. The number of nightly visits of C. sphinx to M. calabura was much higher than to any other commercial fruits (Singaravelan \& Marimuthu, 2006). Thus, it appears that $M$. calabura serves as an effective alternative forage source when planted adjacent to orchards (Singaravelan \& Marimuthu, 2006).

\section{Is it still justifiable to categorize plant-visiting bats as vermin?}

Although there has been much debate about fruit bat damage to commercial orchards, the beneficial role of such bats and the ecological services they provide has not been fully appreciated. Publications in peer-reviewed journals, which detail the ecological roles of those bats (Cox et al., 1991; Fujita \& Tuttle, 1991; Fleming \& Sosa, 1994) may not yet have reached policy makers and conservation planners. In spite of the damage to orchards by the three ubiquitous species (P. giganteus, R. leschenaultii and C. sphinx), their beneficial roles cannot be ignored. Unlike other small mammals, fruit bats usually give birth to a single young (occasionally two, such as Eonycteris), either once (e.g. P. giganteus) or twice (e.g. R. leschenaultii and C. sphinx) per year. If the fruit bats of India are not protected their populations will be drastically reduced because of this low reproductive rate. Such a situation may have a cascading effect on ecosystems, with potentially serious ecological consequences and economic disadvantages (Fujita \& Tuttle, 1991; Elmqvist et al., 1992).

With respect to the other 10 species of pteropodids, in a long-term study with a total of 1,858 mist net hours from April 2000 to August 2003 we never captured individuals of L. salimalii, C. brachyotis and E. spelaea in lowland areas (Singaravelan, 2002; Singaravelan \& Marimuthu, 2006, 2007), and there is no report of the other seven species visiting lowland areas or complaints of damage to orchards. We thus rule out the possibility that these 10 species visit commercial orchards.

We recommend that the remaining 12 species of fruit bats should all be removed from the list of vermin in the Indian Wildlife (Protection) Act and placed in Schedule I along with $L$. salimalii. Detailed long-term studies on the distribution, breeding and foraging behaviour of all 10 species of pteropodids that live in the forests of India should be a priority.

\section{Acknowledgements}

The MoEF, Government of India, supported the work through a grant to GM. NS acknowledges the support of 
a scholarship from Bat Conservation International. We are grateful to Richard Jenkins for comments on the draft manuscript and two anonymous referees for their critical comments.

\section{References}

A uL, B. (2006) Status, distribution and ecological studies of the bats in the Andaman and Nicobar islands with special reference to the Nicobar flying fox (Pteropus faunulus). PhD thesis, Madurai Kamaraj University, Madurai, India.

Baker, H.G. \& Harris, B.J. (1957) The pollination of Parkia by bats and its attendant evolutionary problems. Evolution, 11, 449-460.

Balasingh, J., Ronald, J., Thiruchenthil, N.P. \& Suthakar, I.S. (1999) Occurrence of Cynopterus brachyotis (Chiroptera: Pteropodidae) in Kalakad Mundanthurai Tiger Reserve, southern India. Current Science, 76, 1542.

BANACK, S.A. (1998) Diet selection and resource use by flying foxes (genus Pteropus). Ecology, 79, 1949-1967.

Bates, P.J.J. \& Harrison, D.L. (1997) Bats of the Indian Subcontinent. Harrison Zoological Museum, Sevenoaks, UK.

B A W A, K.S. (1990) Plant-pollinator interactions in tropical rainforests. Annual Review of Ecology and Systematics, 21, 399-422.

Bonaccorso, F.J. \& Gush, T.J. (1987) An experimental study of the feeding behaviour and foraging strategies of phyllostomid fruit bats. Journal of Animal Ecology, 56, 907-920.

Brosset, A. (1962) The bats of central and western India Part I. Journal of the Bombay Natural History Society, 59, 1-57.

Bumrungsri, S., Harbit, A., Benzie, C., Carmouche, K., SRidith, K. \& Racey, P.A. (2008) The pollination ecology of two species of Parkia (Mimosaceae) in Southern Thailand. Journal of Tropical Ecology, 24, 467-475.

Charles-Dominique, P. (1986) Inter-relation between frugivorous vertebrates and pioneer plants: Cecropia, birds and bats in French Guyana. In Frugivores and Seed Dispersal (eds A. Estrada \& T.H. Fleming), pp. 91-110. Dr. W. Junk, Dordrecht, The Netherlands.

Corlett, R.T. (1998) Frugivory and seed dispersal by vertebrates in the Oriental (Indomalayan) region. Biological Reviews, 73, 413-448.

Corlett, R.T. (2004) Flower visitors and pollination in the Oriental (Indomalayan) region. Biological Reviews, 79, 497-532.

Cox, P.A., Elmqvist, T., Pierson, E.D. \& Rainey, W.E. (1991) Flying foxes as strong interactors in South Pacific Island ecosystems: a conservation hypothesis. Conservation Biology, 5, 448-454.

Devy, M.S. \& Davidar, P. (2003) Pollination systems of trees in Kakachi, a mid-elevation wet evergreen forest in Western Ghats, India. American Journal of Botany, 90, 650-657.

Elmqvist, T., Cox, P.A., Rainey, W.A. \& Pierson, E.D. (1992) Restricted pollination on oceanic islands: pollination of Ceiba pentandra by flying foxes in Samoa. Biotropica, 24, 15-23.

Fleming, T.H. \& Estrada, A. (1993) Frugivory and Seed Dispersal: Ecological and Evolutionary Aspects. Kluwer Academic, Dordrecht, The Netherlands.

FLEMING, T.H. \& SosA, V.J. (1994) Effects of nectarivorous and frugivorous mammals on reproductive success of plants. Journal of Mammalogy, 75, 845-851.

Fujita, M.S. (1988) Flying foxes and economics. Bats, 6, 4-9.

Fujita, M.S. \& Tuttle, M.D. (1991) Flying foxes (Chiroptera: Pteropodidae): threatened animals of key ecological and economic importance. Conservation Biology, 5, 455-463.

Gould, E. (1978) Foraging behaviour of Malaysian nectar-feeding bats. Biotropica, 10, 184-193.
Hall, L.S. \& RichaRds, G.C. (1987) Crop protection and management of flying-foxes (Chiroptera: Pteropodidae). Australian Mammalogist, 10, 137-139.

Izhaki, I., Korine, C. \& Arad, Z. (1995) The effect of bat dispersal (Rousettus aegyptiacus) on seed germination in eastern Mediterranean habitats. Oecologia, 101, 335-342.

Jacobsen, N.H.G. \& DuPlessis, E. (1976) Observations on the ecology and biology of the cape fruit bat Rousettus aegyptiacus leachi in the Eastern Transvaal. South African Journal of Science, $72,270-273$.

JanZen, D.H. (1983) Food webs: who eats what, why, how and with what effects in a tropical forest? In Ecosystems of the World. $14 \mathrm{~A}$. Tropical Forest Ecosystems, Structure and Function (ed. F.B. Golley), pp. 167-182. Elsevier Scientific Publishing Co, New York, USA.

LAW, B.S. \& LeAN, M. (1999) Common blossom bats (Syconycteris australis) as pollinators in fragmented Australian tropical rainforest. Biological Conservation, 91, 201-212.

Loebel, R. \& Sanewski, G. (1987) Flying-foxes (Chiroptera: Pteropodidae) as orchard pests. Australian Mammalogist, 10, 147-150.

Loveless, M.D. \& HAMrick, J.L. (1984) Ecological determinants of genetic structure in plant populations. Annual Review of Ecology and Systematics, 15, 65-96.

Marshall, A.G. (1983) Bats, flowers and fruit: evolutionary relationships in the Old World. Biological Journal of the Linnaean Society, 20, 115-135.

Marshall, A.G. (1985) Old World phytophagous bats (Megachiroptera) and their food plants: a survey. Zoological Journal of the Linnaean Society, 83, 351-369.

MCCANN, C. (1931) On the fertilization of flowers of the sausage tree Kigelia pinnata by bats. Journal of the Bombay Natural History Society, 35, 467-471.

McCann, C. (1933) The flying fox (Pteropus giganteus) and the palm squirrel (Funambulus tristriatus) as agents of pollination in the silky oak (Grevillea robusta A. Cunn). Journal of the Bombay Natural History Society, 36, 761-764.

Mickleburgh, S.P., Hutson, A.M. \& Racey, P.A. (1992) Old World Fruit Bats: An Action Plan for their Conservation. IUCN/ Species Survival Commission Chiroptera Specialist Group, IUCN, Gland, Switzerland and Cambridge, UK.

Mickleburgh, S.P., Hutson, A.M. \& Racey, P.A. (2002) A review of the global conservation status of bats. Oryx, 36, 18-34.

Mistry, S. (2003) Protecting the bats of India. Bats, 21, 8-11.

Molur, S., Marimuthu, G., Srinivasulu, C., Mistry, S., Hutson, A.M., Bates, P.J.J. et al. (eds) (2002) Status of South Asian Chiroptera: Conservation Assessment and Management Plan (C.A.M.P.) Workshop Report, 2002. Zoo Outreach Organization, CBSG South Asia and WILD, Coimbatore, India.

Moran, S. \& Keidar, H. (1993) Checklist of vertebrate damage to agriculture in Israel. Crop Protection, 12, 171-182.

Muscarella, R. \& Fleming, T.H. (2007) The role of frugivorous bats in tropical forest succession. Biological Reviews, 82, 573-590.

Nathan, P.T., Raghuram, H., Elangovan, V., Karuppudurai, T. \& MARimuthu, G. (2005) Bat pollination of kapok tree, Ceiba pentandra. Current Science, 88, 1679-1681.

Nelson, J.E. (1965) Behaviour of Australian Pteropodidae (Megachiroptera). Animal Behaviour, 13, 544-575.

Richards, G.C. (1995) A review of ecological interactions of fruit bats in Australian ecosystems. Symposium of Zoological Society of London, 67, 79-96.

Simmons, N. (2005) Chiroptera. In Walker's Mammals of the World. A Taxonomic and Geographic Reference, 3rd edition (eds D.E. Wilson \& D.-A. Reeder), pp. 312-529. John Hopkins University Press, Baltimore, USA. 
Singaravelan, N. (2002) Foraging behaviour of fruit bats in orchards. PhD thesis, Madurai Kamaraj University, Madurai, India.

Singaravelan, N. \& Marimuthu, G. (2003) Mist-net captures of the rarest fruit bat Latidens salimalii. Current Science, 84, 24-26.

Singaravelan, N. \& Marimuthu, G. (2004) Nectar feeding and pollen carrying from Ceiba pentandra by pteropodid bats. Journal of Mammalogy, 85, 1-7.

Singaravelan, N. \& Marimuthu, G. (2006) Muntingia calabura - an attractive food plant of Cynopterus sphinx-deserves planting to lessen orchard damage. Acta Chiropterologica, 8 , 239-245.

Singaravelan, N. Raja, R. \& Marimuthu, G. (2007) Nectar feeding strategies of Pteropodid bats on Parkia biglandulosa: the influence of angular variations in nectar rings. Proceedings of the Indian National Science Academy, 73, 127-135.

Srinivasulu, B. \& Srinivasulu, C. (2001) Magnitude of depredation on grapes by short-nosed fruit bats Cynopterus sphinx Vahl, 1797 in Secunderabad, India. Current Science, 80, $14-15$.

Srinivasulu, C. \& Srinivasulu, B. (2002) Greater short-nosed fruit bat (Cynopterus sphinx) foraging in vineyards in India. Acta Chiropterologica, 4, 167-172.

Start, A.N. \& Marshall, A.G. (1976) Nectarivorous bats as pollinators of trees in West Malaysia. In Variation, Breeding and Conservation of Tropical Forest Trees (eds J. Burley \& B.T. Styles), pp. 141-150. Academic Press, London, UK.

Subramanya, S. \& Radhamani, T.R. (1993) Pollination by birds and bats. Current Science, 65, 201-209.

Tidemann, C.R., Kelson, S. \& Jamieson, G. (1997) Flying-fox damage to orchard fruit in Australia-incidence, extent and economic impact. Australian Biologist, 10, 177-184.
Tidemann, C.R. \& Nelson, J.E. (1987) Flying foxes (Chiroptera: Pteropodidae) and bananas: some interactions. Australian Mammalogy, 10, 133-136.

VAN DER PIJL, L. (1956) Remarks on pollination by bats in the genera Ferycinetia, Duabanga and Haplophragma and on the chiropterophily in general. Acta Botanica Neerdelandica, 5, 135-144.

VAN DER PijL, L. (1961) Ecological aspects of flower evolution. II. Zoophilous flower classes. Evolution, 15, 44-59.

VergheEse, A. (1998) Non-destructive control of the bat, Cynopterus sphinx Vahl (Chiroptera: Pteropodidae) in grapes (Vitis vinifera Linnaeus) in India. International Journal of Pest Management, 44, $81-85$.

WAnG, B.C. \& S Sith, T.B. (2002) Closing the seed dispersal loop. Trends in Ecology \& Evolution, 17, 379-386.

Young, A., Boyle, T. \& Brown, T. (1996) The population genetic consequences of habitat fragmentation for plants. Trends in Ecology \& Evolution, 11, 413-418.

\section{Biographical sketches}

Natarajan Singaravelan has studied behavioural and conservation ecology of plant-visiting bats. He is a member of the Chiroptera Conservation Information Network of South Asia (CCINSA) and is popularizing the conservation needs of bats in general and the vital role they play in restoration ecology. GANAPATHY MARIMUTHU has worked on bats throughout his career. He is a member of the Bat Specialist Group of IUCN's Species Survival Commission and was founding Chairman of CCINSA. PAUL RACEY works on the ecology and conservation biology of bats in temperate and tropical latitudes, particularly Madagascar. He is Co-Chair of IUCN's Bat Specialist Group and is Vice Chairman of Fauna \& Flora International. 